\title{
The Application of the LDL Principle
}

\author{
David S. Schade1, Brendan Cavanaugh'2, Barry Ramo², R. Philip Eaton ${ }^{1}$ \\ ${ }^{1}$ Division of Endocrinology, DolM, School of Medicine, University of New Mexico, Albuquerque, NM, USA \\ ${ }^{2}$ New Mexico Heart Institute, Albuquerque, NM, USA \\ Email: dschade@salud.unm.edu
}

Received 31 March 2016; accepted 17 May 2016; published 20 May 2016

Copyright (C) 2016 by authors and Scientific Research Publishing Inc.

This work is licensed under the Creative Commons Attribution International License (CC BY).

http://creativecommons.org/licenses/by/4.0/

(c) (i) Open Access

\section{Abstract}

The LDL Principle has recently been invoked to describe the observation that lowering the LDL cholesterol (by whatever means) results in a lowering of atherosclerotic cardiovascular events. The scientific basis of the LDL Principle dates back to the discovery that the LDL receptor is the prime determinant of the circulating LDL-c concentration. Since that time, major advances have been made at both the basic and clinical science level in our understanding of the pathogenesis and reversal of atherosclerosis. The incorporation of atherogenic lipoproteins plus inflammatory mediators into plaque formation permits the targeted intervention into preventing plaque rupture. In addition, genetic studies identifying individuals with unique phenotypes of either abnormally high or low LDL-c concentrations have provided insight into possible therapeutic modalities that have recently provided the physician with the tools necessary to apply the LDL Principle to achieve reversal of atherosclerosis. The epidemic of atherosclerotic cardiovascular disease has resulted in numerous randomized controlled intervention trials in an attempt to identify approaches to reduce ASCD morbidity and mortality. Recently published data indicate that circulating LDL-c levels of $50 \mathrm{mg} / \mathrm{dl}$ or less are not only physiologic at birth but also effective in greatly reducing cardiovascular disease. In addition, the recent availability of two PCSK9 inhibitors provides the primary care physician with the possibility of achieving this low level of LDL-c even in statin intolerant patients. The widespread availability of the coronary artery calcium scan plus the inclusion of traditional cardiovascular risk factors in risk assessment has enabled the physician to readily identify asymptomatic individuals at high risk for cardiovascular events. Aggressively applying the LDL Principle to these individuals has the potential of greatly reducing cardiovascular mortality. This review will document the scientific basis for this principle and provide the arguments in favor of its aggressive application.

\section{Keywords}

LDL Principle, Atherosclerosis, Myocardial Infarction, Atherosclerosis Reversal, LDL Cholesterol 


\section{Introduction}

In the United States, 500,000 individuals die from atherosclerotic cardiovascular disease (ASCD) each year (Figure 1) [1]. This number equates to approximately one death per minute. More people die from cardiovascular disease than all the cancers combined [2]. Furthermore, many of these deaths are in people during their productive years when they are raising a family and contributing to society. During the last several years, the number of individuals dying of heart disease has been in decline. However, this statistic obscures the fact that the

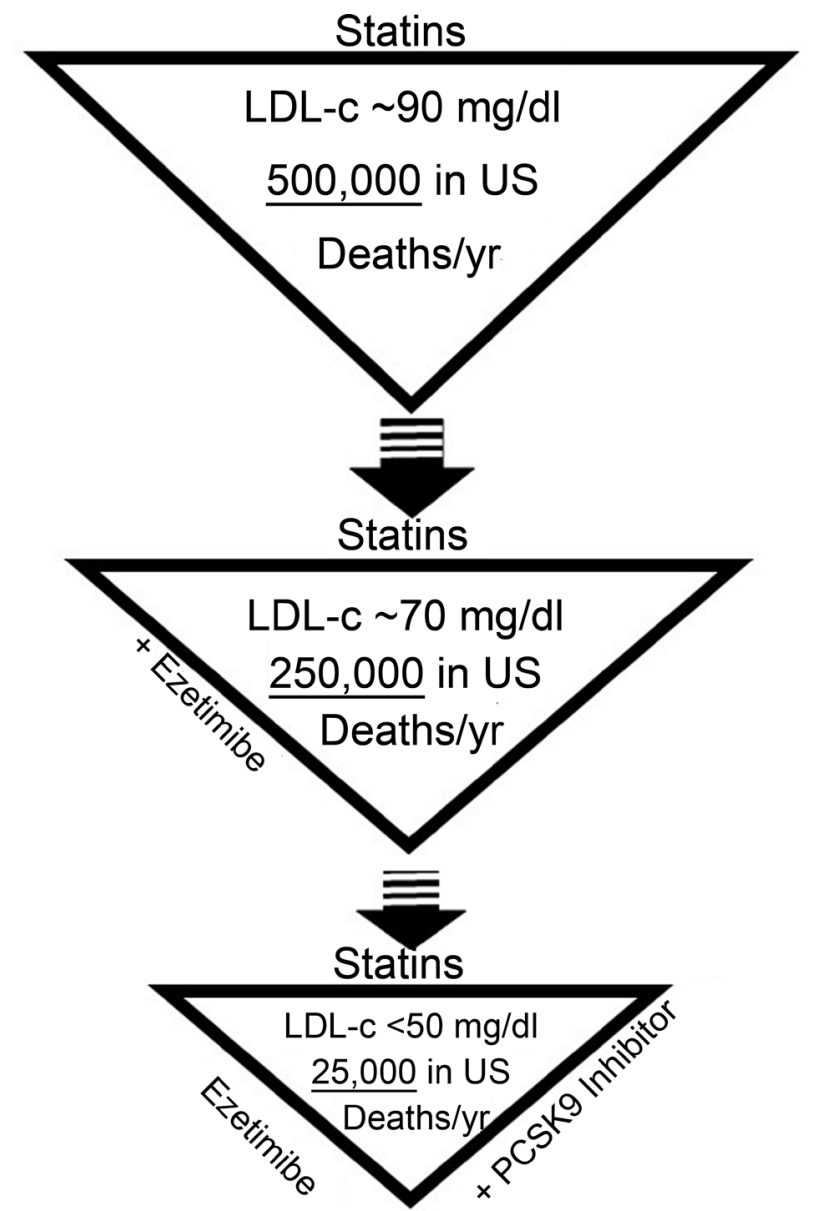

Figure 1. Legend-application of the LDL-c Principle Top triangle. At present, there are approximately 500,000 deaths per year in the U.S. attributed to atherosclerotic cardiovascular disease [1]. The LDL-c of individuals admitted to the hospital due to ASCD have an average LDL-c of $~ 94 \mathrm{mg} / \mathrm{dl}$ [62]. Middle Triangle. Based on the LDL-c Principle (for each reduction in LDL-c, there is a corresponding reduction in ASCD), the death rate should decline to $\sim 250,000$ over 10 years with an LDL-c of $70 \mathrm{mg} / \mathrm{dl}$ [46]. At this LDL-c level, coronary artery disease may be reversible in some individuals with minimal risk factors [52]. Bottom Triangle. A further reduction in LDL-c to $<50 \mathrm{mg} / \mathrm{dl}$ should reduce the CHD death rate to $\sim 25,000 \mathrm{yr}$. At this LDL-c level, coronary artery disease should be reversible in almost all individuals [63]. These predictions are based on the supposition that the duration of therapy is lifelong. Included in the 25,000 cardiovascular deaths are those individuals with genetic hyperlipidemic abnormalities and individuals who cannot take atherosclerotic medications and/or reduce their cardiovascular risk factors via lifestyle changes. 
actual prevalence of heart disease is increasing [3]. The reason for this apparent contradiction is that improved technology is saving lives of heart attack victims. Most disturbing is the fact that the medical establishment employs a very conservative attitude in contrast to an aggressive preventive approach to this epidemic [4]. One reason often cited for this reluctance to aggressively treat subclinical atherosclerosis is the lack of a definitive clinical trial to "prove" efficacy. However, no clinical trial is totally free from bias [5]. Furthermore, many randomized clinical trials are not feasible because a placebo control group is unethical and/or the duration or size of the trial with sufficient power is impractical. For these situations, alternative statistical approaches have been recommended [6]-[9].

Over a decade ago, several prominent professional caregivers including cardiologists, lipidologists, and internists called for a new, aggressive approach to the prevention of ASCD [10] [11]. This request has recently been updated [12]. However, their recommendations have not translated into action by the primary caregivers in the United States. Since these publications, many new studies have been reported, further supporting the contention that atherosclerotic cardiovascular disease is a preventable condition. During the last 30 years, major advances have been made in our understanding of the pathogenesis of atherosclerosis by both basic scientists and clinicians [13]-[16]. Admittedly, there are areas in lipid metabolism and atherosclerosis progression that still need to be explored and explained. However, sufficient knowledge is now available through many scientific publications that the progression and reversal of atherosclerosis are within the ability of the medical establishment. In one form or another, these authors are applying the LDL-c Principle. Figure 2 details the individual components of this principle which will be reviewed in this article. Furthermore, we know that the arterial uptake of low density lipoprotein cholesterol (LDL-c) is primarily responsible for the progression of the atherosclerotic plaque whereas the activity of high density lipoprotein is highly correlated with its removal [17]. These opposing forces continue throughout life beginning in the teenage years with LDL-c slowly predominating with atherosclerotic plaque deposition in many individuals [18].

\section{The Most Important Question}

Given the above cardiovascular mortality and morbidity, rational individuals should be asking "why are we not preventing atherosclerotic heart disease?” The reasons are multifactorial and complex. For example, the average time required for a major medical discovery to be translated into direct benefit to the population is 17 years [19] [20]. As a group, professional caregivers are conservative, learning primarily from the clinical setting rather than

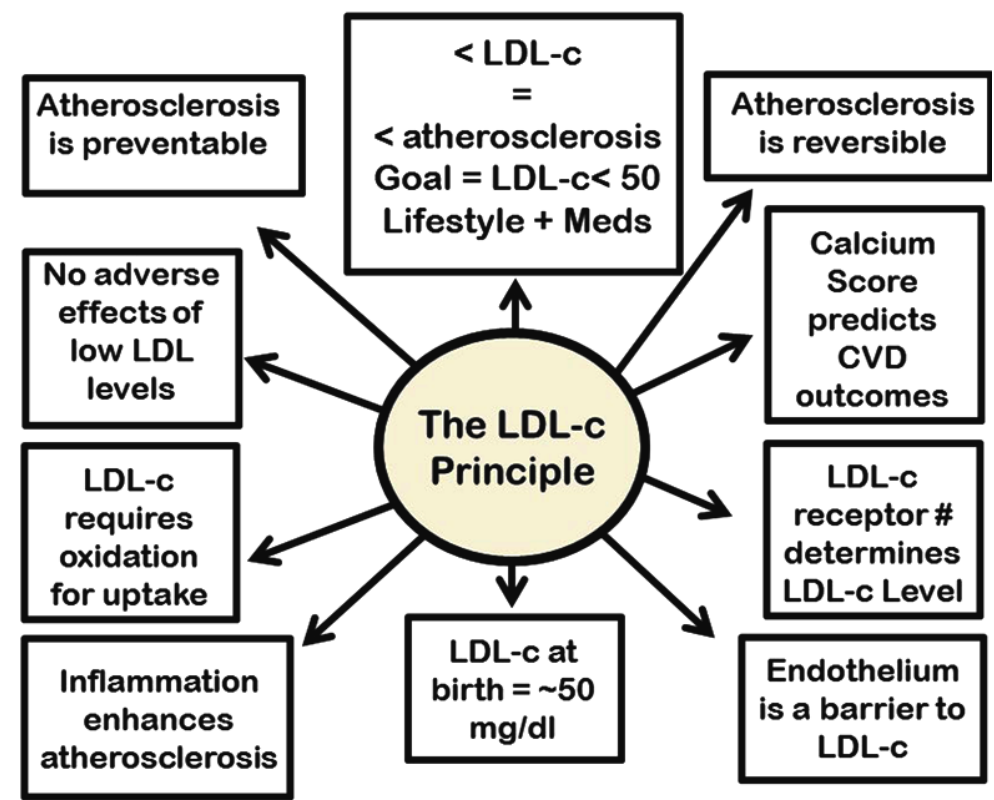

Figure 2. legend-components of the LDL-c Principle-The LDL-c Principle has several components that are listed in the figure. Details of each component are given in the text. 
from recent publications [21]. Physicians themselves generally resist major changes in the way they practice for both nonfinancial and financial reasons [22]. In addition, acquiring new knowledge requires time and effort which are not reimbursed in today's market place [23]. It is much easier to wait for "guidelines" to be published and to follow these recommendations without questioning the rationale or scientific basis for the "expert" advice. Unfortunately, the average age of publications that are listed as supporting published guidelines are 8 years old [20]. Furthermore, many of the cardiovascular treatment guidelines from major organizations are in conflict with each other or with previously published guidelines [24]. Their recommendations reflect the opinions and biases of the individuals composing the organizations' guideline committees [25]-[27].

\section{Pathogenesis of a Coronary Thrombosis}

The detailed steps in progressing from atherosclerotic plaque to coronary thrombosis have been described by Libby and only summarized here [12] [28]. An atherogenic plaque in the coronary artery takes many years to develop [18]. The process begins with the movement of excess LDL-c from the circulation, through the internal endothelial lining and into the vessel's medialsection. This is accompanied by the movement of macrophages from the circulation, which takes up the oxidized LDL-c in the vessel wall via specific macrophage receptors. Eventually, these lipid laden macrophages coalesce into a fatty streak which is the first recognizable structure of a forming plaque. As the process continues, inflammatory substances including cytokines, metalloproteinases, other atherogenic lipoproteins, and thrombogenic substances enter the plaques' lipid core which develops a fibrous cap. This all important cap prevents extrusion of the plaque's content into the vessel lumen. Smooth muscle cells migrate from the vessel's wall to surround the plaque and stabilize it [29]. Calcium also precipitates around the plaque for presumably further stabilization [30]. If the plaque becomes unstable, the fibrous cap will be thinned by inflammatory constituents and eventually the plaque's contents will rupture into the vessel lumen [31]. The core of the plaque contains thrombogenic material which attracts platelets and subsequently a blood clot is formed over the plaque [29]. This vessel occlusion results in a coronary thrombosis. In contrast, stabilization of the plaque involves removal of the lipid contents and thickening of the fibrous cap [32].

\section{Why Focus on LDL-c?}

To be sure, LDL-c is not the only atherosclerotic lipoprotein. Some investigators recommend measuring non HDL cholesterol which includes LDL-c as well as triglyceride remnant lipoproteins and also lipoprotein (a) [33]. Other investigators prefer to measure the apolipoproteins that combine with lipids to form lipid particles [34]. One advantage of this approach is that an accurate estimation of the number of LDL-c particles can be obtained since there is only one apolipoprotein B molecule per LDL-c particle [35]. In addition, inflammatory factors undoubtedly play an important role in the development of the fatty streak and plaque instability [14]. Risk factors such as diabetes, hypertension, family history, low HDL-c and smoking are also important contributors [36]. The importance of an intact endothelial arterial layer is critical for regulating the entrance of LDL-c particles into the sub-endothelial space. This includes the availability of nitric oxide, monocyte adhesion factors, and sufficient anti-oxidants to control the oxidation of LDL-c before uptake by macrophages. Specific receptors on the surface of macrophages for oxidized LDL-c facilitate the pathogenesis of the fatty streak and the atherosclerotic plaque [37] [38]. In patients with renal disease, there are many factors (some known, many unknown) that contribute to atherosclerosis. Lipid lowering with statins may have several beneficial effects in addition to LDL-c lowering in patients with mild to moderate renal disease. However, lipid lowering has not yet been shown to be beneficial for individuals on dialysis [39].

The measurement of LDL-c has limitations. For example, it does not indicate whether the measured LDL-c is primarily composed of large or small LDL-c particles. Studies have demonstrated that small, dense LDL-c particles are more atherogenic than larger, less dense LDL-c particles [34]. Furthermore, the LDL-c level is not usually measured directly, but calculated from the Friedewald equation [40]. This calculation works well when the triglyceride level is close to the normal range but is inaccurate at elevated triglyceride concentrations [41]. However, LDL-c and its subsequent oxidation are the prime instigators of the fatty streak and atherosclerotic plaque. Overall, the LDL-c concentration is a good predictor of future cardiovascular events and has been measured in all atherosclerotic treatment and prevention trials [42]. Most importantly, professional caregivers are familiar with its measurement and it is included in all lipid profile measurements. Thus, until a better predictor of atherosclerosis is readily available and clinically familiar, we recommend its use as the targeted lipoprotein of risk. 


\section{The Importance of the Duration of LDL-c Exposure}

There is at least one major difference between intervention trials to lower LDL-c and population studies which exam LDL-c concentration and the incidence of atherosclerotic cardiovascular disease. Intervention trials usually last up to five years in duration whereas population studies describe LDL-c concentrations that have been present for many years, often since adolescence. This is likely the reason that the reduction in cardiovascular disease by a statin intervention to a specific LDL level is not as great as examining the prevalence of cardiovascular disease at that same level of LDL-c in a population [43]. For example, in individuals with a lifetime nonsense mutations in PCSK9 resulting in a reduction of LDL-c by $38 \mathrm{mg} / \mathrm{dl}$ compared to a similar population of middle aged individuals, cardiovascular disease was reduced by $88 \%$ [44]. In contrast, statin intervention trials which also reduce LDL-c by $\sim 40 \mathrm{mg} / \mathrm{dl}$ reduce cardiovascular disease by only $20 \%$ /yr. [45]. However, what is not often appreciated is the observation that the benefits of statin therapy increase with the duration of treatment. For example, in the 58 statin trials carried out in various populations, for an LDL cholesterol reduction of $\sim 40$ $\mathrm{mg} / \mathrm{dl}$ the risk of cardiovascular events was reduced by $11 \%$ in the first year of treatment, $24 \%$ in the second year, 33\% in years three to five, and by 36\% thereafter ( $p<0.001$ for trend) [46]. These data strongly suggest that LDL-c lowering should begin before advanced atherosclerosis is present.

\section{Traditional Risk Factors}

There are numerous risk factors for atherosclerosis besides atherogenic lipoproteins. Some of these have been demonstrated to be independent risk factors when multivariate statistics have been applied [36]. Traditionally, smoking, hypertension, family history, age, diabetes, sedentary lifestyle, a Westernized diet, and obesity have all been implicated in the pathogenesis of atherosclerotic heart disease. The interplay of these risk factors is complex and difficult to quantify. For example, individuals who demonstrate increased physical fitness have reduced heart disease, but whether it's the physical activity or the difference in lifestyle that goes along with a physically active individual is not resolved [47]. In addition, the Tarahumara Indians who favor exercise and ingest a vegetarian diet, have an average LDL-c of $70 \mathrm{mg} / \mathrm{dl}$ and minimal atherosclerotic risk factors [48]. They are characterized by a very low incidence of cardiovascular disease [49]. However, it is clear that these risk factors do play a major role in accelerating atherosclerosis in most populations. Thus, an individual with diabetes and hypertension may require a lower LDL-c level to reverse atherosclerosis than another individual without these risk factors. For example, a large cohort of people with diabetes and symptomatic ASCD had an average LDL-c of 78 $\mathrm{mg} / \mathrm{dl}$ [50]. Thus, although we recommend that an individual's LDL-c should be less than $50 \mathrm{mg} / \mathrm{dl}$, we also favor an even lower LDL-c in individuals having multiple cardiovascular risk factors.

An alternative lipoprotein often considered a beneficial factor is high density lipoprotein (HDL-c) [51]. In many studies, it has been highly correlated with reverse atherosclerosis [52] [53]. Unfortunately, raising HDL-c via medications, exercise, and weight loss has never been shown to reduce cardiovascular disease [54]. In addition, although HDL-c has many anti-inflammatory properties, during stress states this lipoprotein may exhibit inflammatory characteristics thereby promoting atherosclerosis [55]. For the above reasons, targeting changes in HDL-c as an anti-atherosclerotic goal cannot be recommended at this time.

\section{Lifestyle Changes}

Our focus on the reduction of LDL-c concentration as the principle risk factor to aggressively address should not be interpreted to suggest that a healthy lifestyle should not be part of an atherosclerosis reversal program. Indeed, several of the cardiovascular risk factors described above are secondary to an unhealthy lifestyle. Hypertension, obesity, smoking, an elevated cholesterol, and a high saturated fat diet all contribute to plaque deposition in the coronary arteries [56]. Improved lifestyle should always be the cornerstone of atherosclerosis prevention therapy. This change in behavior should include appropriate exercise and a diet designed to achieve normal body weight with a reduction in saturated fat and an increase in poly unsaturated fatty acids [57]. However, as has been demonstrated in the United States by the epidemic of obesity, lifestyle changes are very difficult to achieve [58]. As discussed below, one approach to motivating patients to improve their lifestyle is to obtain a coronary artery calcium scan to quantitate their atherosclerosis burden [59] [60]. Thus, it is important for caregivers to appreciate the reversibility of atherosclerosis and communicate this information to their patients. 


\section{LDL-c Recommendations}

Current recommendations from most organizationsissuing LDL-c guidelines state that the circulating LDL-c concentration should be $70 \mathrm{mg} / \mathrm{dl}$ or less [61]. This LDL-c level is an improvement over previous recommendations which suggested goals of $100 \mathrm{mg} / \mathrm{dl}$ or even as high as $130 \mathrm{mg} / \mathrm{dl}$. In addition, since the development of atherosclerosis is a life-long process, the duration of LDL-c exposure must also be considered in designing treatment regimens [43].

Unfortunately, all clinical trials to date utilizing the LDL-c goal of $70 \mathrm{mg} / \mathrm{dl}$ demonstrate significant "residual risk” (i.e., individuals experiencing major cardiovascular events) in spite of active LDL-c lowering therapy [51]. The number of individuals experiencing cardiovascular events and death in the "residual risk" category has always been greater than the number of individuals who benefit from the limited experimental LDL-c lowering. Although the authors of these publications are understandably enthusiastic concerning the lives saved and/or ASCD events prevented, very little attention is paid to the residual number of individuals experiencing a cardiovascular event. It should be noted that the average LDL-c for patients entering the hospital with an acute coronary event is below $100 \mathrm{mg} / \mathrm{dl}$ and their HDL-c is above $40 \mathrm{mg} / \mathrm{dl}$ [62]. These data suggest that an LDL-c goal of $70 \mathrm{mg} / \mathrm{dl}$ is not adequate in most individuals with risk factors to reduce atherosclerotic cardiovascular disease to an acceptable level. This conclusion is supported by statin clinical trials in which reversal of atherosclerosis was not observed until the LDL-c was below $70 \mathrm{mg} / \mathrm{dl}$ [63].

A meta-analysis of 26 randomized clinical trials including data from 170,000 participants indicates that further reductions of LDL-c cholesterol safely produce definite further reductions in the incidence of heart attack, coronary revascularization, and ischemic stroke, with each $1.0 \mathrm{mmol} / \mathrm{L}(\sim 39 \mathrm{mg} / \mathrm{dL})$ reduction of LDL-c reducing the annual rate of these major vascular events by $20 \%$ [45]. Over a five year period, this reduction in atherosclerotic events would be substantial. Furthermore, there was no lower limit threshold for this LDL-c reduction implying that the lower the LDL-c concentration, the better [64]. What the cumulative rate of ASCD would be over a ten year period or if the mean LDL-c were reduced to $50 \mathrm{mg} / \mathrm{dl}$ or less has not been directly studied. Thus, none of these trials included an LDL-c goal of $50 \mathrm{mg} / \mathrm{dl}$ or lower, but for participants that did achieve an LDL-c lower than $70 \mathrm{mg} / \mathrm{dl}$, definite benefit was observed without an increase in side effects [45].

\section{LDL-c Receptor}

The circulating LDL-c concentration is determined to a great extent by the number of LDL-c receptors that are present on the hepatic surface. Brown and Goldstein received the Nobel Prize in Medicine for the demonstration that patients who genetically had very high levels of circulating LDL-c were deficient in the hepatic LDL-c receptor [65]. These patients died at a very early age of atherosclerotic cardiovascular disease unless they received a liver transplant to correct the LDL-c receptor deficiency [66]. The determinants of the number of hepatic LDL-c receptors are multiple and complex but both genetics and the hepatic content of unesterified cholesterol are primary determinants [65]. Under normal circumstances, the LDL-c receptor is recycled every ten minutes (approximately 150 times)to the hepatic surface before being degraded [43] [67]. The three primary LDL-c lowering medications (discussed below) all express their LDL-c lowering activity through increasing the concentration of LDL-c receptors on the hepatic surface, albeit by different mechanisms.

\section{How Low and How Safe?}

The critical question that professional caregivers should be asking is how low the patient's LDL-c should be to prevent and/or reverse atherosclerosis? Several intravascular ultrasound studies have demonstrated that reversal may occur at a mean LDL-c concentration of $65 \mathrm{mg} / \mathrm{dl}$ [53] [63] [68]-[70]. However, this level may not be sufficiently low or rapid enough for all patients, particularly individuals with significant risk factors such as smoking, poorly controlled diabetes, and abnormally low HDL-c levels. Furthermore, large statin trials in which the LDL-c concentrations are targeted to $70 \mathrm{mg} / \mathrm{dl}$ or less have uniformly demonstrated that the lower the better without additional side effects [71] [72].

The second question that professional caregivers should ask is what level of LDL-c is safe i.e., how low an LDL-c can be reached without significant side effects. Studies directly addressing this question have only examined LDL-c levels down to $100 \mathrm{mg} / \mathrm{dl}$ [73]. However, there is much indirect information that LDL-c levels below $50 \mathrm{mg} / \mathrm{dl}$ are safe [74]. For example, many healthy people are born with an LDL-c of 40 mg/dl [75] [76]. 
Second, short term (3 months) studies combining both high intensity statins and a PCSK-9 inhibitor have reduced LDL-c levels to 35 to $38 \mathrm{mg} / \mathrm{dl}$ without additional side effects compared to placebo [77]. Recent studies utilizing PCSK9 inhibitors resulting in a mean LDL-c concentration of $40 \mathrm{mg} / \mathrm{dl}$ have resulted in a reduction in cardiovascular events without serious side effects [78]. Since every cell in the body has its own inherent ability to synthesize cholesterol, the necessity to obtain cholesterol from circulating LDL-c in the adult has not been demonstrated. In addition, one adult individual with a genetic deficiency of PCSK-9 has an LDL-c concentration of $14 \mathrm{mg} / \mathrm{dl}$ with no apparent ill effects [79].

\section{Medications}

Statins-As important as this pathogenic knowledge of atherosclerosis is, even more important is the fact that professional caregivers now have the medications available to reverse the arterial atherosclerotic process by aggressively lowering LDL-c and reducing inflammation [80] [81]. With the availability of high potency statins (atorvastatin and rosuvastatin), dramatic decreases in LDL are now possible [82]-[85]. Significant decreases in cardiovascular events have been observed in numerous statin trials (Cholesterol Treatment Trialists' (CTT) Collaboration). Several studies using coronary artery CT angiography have directly demonstrated that statins reduce non-calcified plaque [86] [87]. Furthermore, atherosclerotic plaques can be stabilized within one month of initiating statin therapy by reducing the plaque's lipid content and inflammatory constituents [88]. They also increase the thickness of the lesions fibrous cap, increasing its stabilization [89]. An unstable plaque may rupture into the coronary vessel lumen and initiate a blood clot with subsequent vessel occlusion [12].

The challenge now is to convince patients to take these anti-atherosclerotic medications. Fifty percent of patients are no longer taking prescribed statins after two years [90]. It is clear that patients who take their prescribed statin medication have lower hospitalization costs at two years than patients who do not take their medications [91]. A coronary artery calcium scan (discussed below) often results in improved patient compliance with statins and aspirin [92]. Practically every study of long term statin use has shown that the benefits of statins outweigh the risks, even in individuals without established cardiovascular disease but with cardiovascular risk factors [93]. The principal reported risks of statins include an elevation of liver enzymes, myalgias, diabetes and cognitive impairment.

Statin induced severe liver function abnormalities are rare. In fact, the FDA no longer requires periodic monitoring of liver function tests in patients taking statins [94]. Myalgias and severe myopathies are also rare-approximately one in 10,000 with simvastatin [95]. Recent blinded studies emphasize that even in patients who state they cannot take statins because of perceivedmyalgias, almost none of these individuals are actually statin intolerant [96]. In addition, low doses of rosuvastatin can be given intermittently to individuals who believe that they are truly statin intolerant with good results [97]. In the 26 randomized statin trials in which a statin high dose was compared to either a low statin dose or placebo, all of the excess cases of rhabdomyolysis (10 versus none) occurred with high dose simvastatin therapy (80 mg/day) [95]. In these five trials, the rate of excess rhabdomyolysis was four cases per 10,000 volunteers. This excess has not been reported with the newer, more potent statins, atorvastatin and rosuvastatin. Statin induced myalgias, when assessed in double blinded studies, are more common but still relatively rare [98]. Based on a review of healthy clinical-trial participants, the placebo-corrected incidences of minor muscle pain, myopathy (with significant elevations in creatinine kinase), and rhabdomyolysis are 190, 5, and 1.6 per 100,000 patient years, respectively [99].

In spite of claims to the contrary, statins do not directly cause diabetes [100]. What they do cause is a small elevation in fasting glucose, approximately $2 \mathrm{mg} /$ dlin non-diabetic individuals [101]. There has never been a report of a patient with normal glucose tolerance being placed on a statin who then rapidly developed diabetes. What has been reported in population studies is that a certain percentage of patients placed on a statin meet the criteria for diabetes with a fasting glucose of $126 \mathrm{mg} / \mathrm{dl}$ or a hemoglobin A1C of 6.6\% [101]. These patients likely had prediabetes (with a fasting glucose of 122 to $125 \mathrm{mg} / \mathrm{dl}$ or a hemoglobin A1C of 6.4\%) prior to taking a statin and the small rise in glucose induced by the statin raised them into the diabetic range of glucose intolerance. It should be noted that all side effects of statins are dose dependent and therefore the lowest dose of a statin that can achieve an LDL-c below $50 \mathrm{mg} / \mathrm{dl}$ should be used. The concurrent use of ezetimibe $(10 \mathrm{mg})$ and a high potency statin $(10 \mathrm{mg})$ will often achieve this goal in most individuals who start with an LDL-c of approximately $100 \mathrm{mg} / \mathrm{dl}$. This prediction is based on the observations that $10 \mathrm{mg} / \mathrm{d}$ of atorvastatin will lower LDL-c by $40 \%$ and ezetimibe by an additional 24\% [102] [103]. Finally, numerous case reports in the literature 
suggest that statins are responsible for cognitive impairment. However, a recent review and meta-analysis does not support these allegations [104] [105]. Furthermore, other reviews are in agreement and also suggest that there is preliminary evidence of a beneficial effect of statins on many cognitive functions [106]. On balance, if statins do cause mental impairment, it must be a rare occurrence.

Cholesterol blockers-The majority of free cholesterol $(3 / 4=1500 \mathrm{mg} / \mathrm{day})$ absorbed through the intestinal tract is derived from cholesterol secreted into the biliary tract by the liver [107]. This quantity increases the cholesterol content of the liver with a subsequent decrease in hepatic LDL-c receptors. Directly blocking the intestinal cholesterol receptor with ezetimibe will reduce free cholesterol absorption by $50 \%$, decrease the hepatic content of cholesterol, and increase hepatic LDL-c receptors [108]. High intestinal cholesterol absorption has been shown to be associated with increased cardiovascular disease [109]. Studies have demonstrated that there is a specific receptor in the intestine critical for cholesterol absorption-the Nieman-Pick C1 Like 1 protein receptor [108] [110]. Ezetimibe directly blocks this receptor.

Individuals with genetic polymorphisms in the intestinal cholesterol receptor "loss of function" have low LDL-c levels and a low incidence of atherosclerotic heart disease [111] [112]. Inactivating mutations of this receptor provides protection from coronary artery disease [113]. This medication will lower LDL-c approximately $24 \%$ and increase LDL receptors on the liver [103]. One advantage of this medication is that it works at a different anatomical location from statins and reduces LDL-c with minimal side effects [114]. It does not increase the incidence of myalgias when used in conjunction with a statin [115].

PCSK9-The recent FDA approval of two proprotein convertase subtilisin/kexintype (PCSK9) inhibitors (alirocumab and evolocumab) provides the physician with a potent class of medications to lower LDL-c levels if a statin and ezetimibe do not achieve the $<50 \mathrm{mg} / \mathrm{dl}$ goal [116] [117]. PCSK9 inhibitors prevent the binding of the PCSK9 protein with the LDL-c receptor, thereby preventing the catabolism of hepatic LDL-c receptors and thus significantly lowering circulating LDL-c [78] [118]. Since the effectiveness of high dosages of potent statins is limited by statins' increase in the PCSK9 protein, the PCSK9 inhibitors enhance the LDL-c lowering effects of statins [119]. This internal feedback regulation of LDL receptors is counterproductive to achieving a major reduction in circulating LDL-c concentration. Granted, additional long term safety experience needs to be gained with these agents which lower the circulating PCSK9 protein. However, short term phase 2 and phase 3 studies have not identified any serious side effects [120]. In addition, combinations of a PCSK9 inhibitor plus either a statin or ezetimibe or both were effective at additionally lowering LDL-c without an increase in serious side effects compared to placebo [77]. Variations in the genetic sequence of the PCSK9 protein which reduce its activity (loss of function) result in a reduction in LDL-c and protection against cardiovascular disease [45]. Plasma PCSK9 levels are predictive of recurrent clinical events in a cohort of patients with stable cardiovascular disease treated with a low dose of atorvastatin [121].

One advantage of the above medications is that they all possess other beneficial effects on lipids and inflammation besides lowering LDL-c. For example, statins (at least in higher dosages) raise HDL-c and part of their anti-atherosclerotic effects has been attributed to this activity [53] [122]. More importantly, many of the plaque stabilizing effects of statins have been attributed to their anti-inflammatory effects [42]. In fact, the anti-inflammatory effects of statins may be equally important to prevention of heart attacks as their inhibitory effects on cholesterol synthesis [42]. These effects are observed within weeks of beginning statins, too soon to be related to their LDL-c lowering activity [123]. Ezetimibe has similar beneficial effects, although not as pronounced as statins [114]. Recent studies have also demonstrated beneficial effects of PCSK9 inhibitors, aside from their LDL-c lowering activity [124]. It is difficult to separate the LDL-c lowering effects from the other beneficial effects since the ratio may depend on the characteristics (i.e., the presence of cardiovascular risk factors) of the population being treated.

\section{Identification of Patients at Risk}

The availability of potent medications that lower LDL-c to less than $50 \mathrm{mg} / \mathrm{dl}$ would not be of much benefit to the professional caregiver if he/she did not have a rapid, non-invasive, inexpensive method to diagnose coronary artery atherosclerosis. Fortunately, recent studies have demonstrated that a coronary artery calcium scan meets all of these requirements [125]-[127]. This test, which requires approximately 10 minutes to complete (with minimal radiation exposure), is rapidly becoming widely available. In most cities, the test costs less than $\$ 200$. It is the best, non-invasive test to predict future cardiovascular events [92] [128]-[130]. The test is most valuable in 
the asymptomatic patient with no known cardiovascular disease. When coronary artery calcium scan is combined with traditional risk factors, even better predictions are achieved [129]. The coronary artery calcium test has been shown to be even superior to coronary artery angiography (for non-hemodynamic coronary lesions) which is invasive and much more expensive [131] [132]. The reason for this advantage is that the majority of coronary events occur in areas of the coronary artery that have no obstructive lesions [15] [131].

The major limitation of coronary calcium scanning is its inability to detect non-calcified plaque [133]. This is the primary reason that individuals with a negative coronary calcium score still have a small, but definite rate of cardiovascular events. These non-calcified plaques may become unstable and rupture. They can be detected using coronary artery CT angiography, but this procedure is more technologically changeling, more expensive, and requires the intravenous administration of contrast material. A recent multicenter study of this technology in symptomatic patients did not demonstrate an improved clinical outcome after two years [134]. However, the protocol did not specify aggressive anti-atherosclerotic therapy for those individuals with coronary artery plaques and no LDL-c treatment goals were recommended.

An important question concerning the coronary calcium scan is "at what age should the test first be ordered". Since many individuals die from cardiovascular disease in their early $50 \mathrm{~s}$, we recommend that scanning for coronary artery calcium begun at the age of 40 years, particularly in high risk individuals (diabetes, hypertension, smokers, low HDL, etc.) [135]. Coronary artery calcium scanning has initiated a paradigm shift in patients with diabetes [2]. For example, coronary artery calcium scanning in healthy, asymptomatic type 1 diabetic individuals with a mean age of 43 years demonstrated a 31\% positive coronary artery calcium score [136]. Recent American Heart Association (AHA) guidelines recommend treating patients with statins according to their risk category, with high risk individuals being treated with high dose statins and lower risk individuals being treated less aggressively [137]. However, assessment of 7000 asymptomatic individuals in the MESA clinical trial demonstrated that approximately $50 \%$ of individuals recommended for treatment with statins according to AHA guidelines actually had a zero calcium score making it very unlikely that these individuals would have a cardiovascular event within the next five years [138]. We recommend that before the physician start a statin in an asymptomatic patient, that a coronary artery calcium score be obtained in order to prevent inappropriate and unnecessary statin therapy [139]. In addition, the use of the MESA website CHD risk score calculator (https://www.mesa-nhlbi.org/MESACHDRisk/MesaRiskScore/RiskScore.aspx) will provide a risk assessment that combines both the coronary artery calcium score and traditional Framingham risk categories [129]. The coronary calcium score has demonstrated good predictability even in high risk individuals under the age of 45 years [140].

The coronary artery calcium score should be repeated at future intervals if the score is zero or low (we recommend five years) so that anti-atherosclerotic therapy can be initiated in a timely fashion. For higher calcium scores, a more frequent repeat calcium score may be indicated. By repeating the test, additional information may be gained because the rate of progression of the calcium score is also a significant predictor of future cardiovascular events [141]. However, since statins increase coronary artery plaque calcium (theoretically as a method of stabilizing the plaque), a decrease in a calcium score for patients placed on statins should not be anticipated [86] [142].

The reason to repeat a calcium score at periodic intervals is that the rate of coronary artery calcium progression has important prognostic significance [133]. Using data from the MESA clinical trial composed of approximately 7000 asymptomatic community based individuals, Budoff et al. demonstrated that individuals who progress from a baseline "0" calcium score to a positive score had a 1.5 times increase in the risk for atherosclerotic heart disease. Annual coronary calcium scores greater or equal to 100 units were associated with a 2.5 to 3.0 times increase in risk [141]. In addition, individuals with diabetes who have progression of atherosclerosis may need additional therapy [143].

\section{Conclusions}

It is clear that professional caregivers now have the tools to rapidly diagnose and prevent ASCD death in their patients. Cost analyses to date have supported the use of statins in both primary and secondary prevention [93] [144]. Unfortunately, all cost analyses do not incorporate the human suffering and loss to family members of productive citizens who die from cardiovascular disease. The critical issue facing all professional caregivers making treatment decisions for their patients is: “do the benefits outweigh the risks?” For 500,000 Americans 
who will die from ASCD each year, the benefit of aggressive anti-atherosclerotic therapy is clearly improved health and life. The risks include medication side effects (which are minimal for the majority of individuals), cost of medications (which must be balanced against the cost of emergency room visits and invasive cardiac procedures), and unknown future side effects from anti-atherosclerotic medications. Unfortunately, the reason that more professional caregivers do not aggressively treat atherosclerosis is not because they conclude that the risks outweigh the benefits. It is because behavioral change is extremely difficult. Acquiring the knowledge of anti-atherosclerotic therapy requires time from a busy schedule, and their institutions and businesses lack the financial incentive to support this approach [145].

The LDL hypothesis, i.e., that a reduction in circulating LDL-c concentration results in a reduction in cardiovascular events, has been supported by many statin clinical trials. However, since statins have pleotropic effects beyond their LDL-c lowering capability, questions have been raised as to whether the benefits are due primarily to the anti-inflammatory effects of statins [42]. With the publication of the IMPROVE-IT clinical trial in which a non-statin medication reduced LDL-c with a concomitant lowing of cardiovascular events, the LDL-c hypothesis has been verified [103]. The term "LDL-c Principle” has been suggested to emphasize this observation [64]. Our article reviews the application of this principle in reducing and reversing cardiovascular disease. Recent guidelines are also endorsing this approach [4] [146]. The challenge is now to translate these observations into treatment realities.

\section{References}

[1] Mozaffarian, D. and Ludwig, D.S. (2015) The 2015 US Dietary Guidelines: Lifting the Ban on Total Dietary Fat. JAMA, 313, 2421-2422. http://dx.doi.org/10.1001/jama.2015.5941

[2] Hecht, H.S. and Narula, J. (2012) Coronary Artery Calcium Scanning in Asymptomatic Patients with Diabetes Mellitus: A Paradigm Shift. Journal of Diabetes, 4, 342-350. http://dx.doi.org/10.1111/j.1753-0407.2012.00212.x

[3] Fuster, V. and Mearns, B.M. (2009) The CVD Paradox-Mortality vs Prevalence Nature Reviews. Cardiology, 6, 669. http://dx.doi.org/10.1038/nrcardio.2009.187

[4] Grundy, S.M. (1999) Primary Prevention of Coronary Heart Disease: Integrating Risk Assessment with Intervention. Circulation, 100, 988-998. http://dx.doi.org/10.1161/01.CIR.100.9.988

[5] Hellman, S. and Hellman, D.S. (1991) Of Mice But Not Men—Problems of the Randomized Clinical Trial. The New England Journal of Medicine, 324, 1585-1589. http://dx.doi.org/10.1056/NEJM199105303242208

[6] Libby, P. (2005a) The Forgotten Majority: Unfinished Business in Cardiovascular Risk Reduction. Journal of the American College of Cardiology, 46, 1225-1228. http://dx.doi.org/10.1016/j.jacc.2005.07.006

[7] Palmer, C.R. and Rosenberger, W. (1999) Ethics and Practice: Alternative Designs for Phase III Randomized Clinical Trials. Controlled Clinical Trials, 20, 172-186. http://dx.doi.org/10.1016/S0197-2456(98)00056-7

[8] Tenhave, T.R., Coyne, J., Salzer, M. and Katz, I. (2003) Research to Improve the Quality of Care for Depression, Alternatives to the Simple Randomized Clinical Trial. General Hospital Psychiatry, 25, 115-123. http://dx.doi.org/10.1016/S0163-8343(02)00275-X

[9] Braunholtz, D.A., Edwards, S.J.L, Richard, J. and Lilford, R.J. (2001) Are Randomized Clinical Trials Good for Us (in the Short Term)? Evidence for a “Trial Effect”. Journal of Clinical Epidemiology, 54, 217-224. http://dx.doi.org/10.1016/S0895-4356(00)00305-X

[10] Naghavi, M., Libby, P., Falk, E., Casscells, S.W., Litovsky, S. and Rumberger, J. (2003) From Vulnerable Plaque to Vulnerable Patient-Part I. Circulation, 108, 1664-1672.

[11] Grundy, S.M., Cleeman, J.I., Merz, N.B., Brewer, H.B., Clark, L.T. and Hunninghake, D.B. (2004) Implications of Recent Clinical Trials for the National Cholesterol Education Program—Adult Treatment Panel III Guidelines. Circulation, 110, 227-239. http://dx.doi.org/10.1161/01.CIR.0000133317.49796.0E

[12] Libby, P. (2013) Mechanisms of Acute Coronary Syndromes and Their Implications for Therapy. The New England Journal of Medicine, 368, 2004-2013. http://dx.doi.org/10.1056/NEJMra1216063

[13] Hansson, G.K. (2005) Inflammation, Atherosclerosis, and Coronary Artery Disease. The New England Journal of Medicine, 352, 1685-1695. http://dx.doi.org/10.1056/NEJMra043430

[14] Libby, P. (2002) Atherosclerosis: The New View. Scientific American, 286, 46-55. http://dx.doi.org/10.1038/scientificamerican0502-46

[15] Maddox, T.M., Stanislawski, M.A., Grunwald, G.K., Bradley, S.M., Ho, P.M. and Tsai, T.T. (2014) Nonobstructive Coronary Artery Disease and Risk of Myocardial Infarction. JAMA, 312, 1754-1763.

[16] Sanz, M.D., Moreno, P.R. and Fuster, V. (2009) The Year in Atherothrombosis. Journal of the American College of 
Cardiology, 53, 1326-1337. http://dx.doi.org/10.1016/j.jacc.2008.12.047

[17] Rohatgi, A., Khera, A., Berry, J.D., Givens, E.G., Ayers, C.R., Wedin K.E., et al. (2014) HDL Cholesterol Efflux Capacity and Incident Cardiovascular Events. The New England Journal of Medicine, 371, 2383-2393. http://dx.doi.org/10.1056/NEJMoa1409065

[18] Tuzcu, E.M., Kapadia, S.R., Tutar, E., Ziada, K.M., Hobbs, R.E.M., McCarthy, P.M., et al. (2001) High Prevalence of Coronary Atherosclerosis in Asymptomatic Teenagers and Young Adults. Circulation, 103, 2705-2710. http://dx.doi.org/10.1161/01.CIR.103.22.2705

[19] Morris, Z.S., Wooding, S. and Grant, J. (2011) The Answer Is 17 Years, What Is the Question: Understanding Time Lags in Translational Research. Journal of the Royal Society of Medicine, 104, 510-520. http://dx.doi.org/10.1258/jrsm.2011.110180

[20] Grant, J., Cottrell, R., Cluzeau, F. and Fawcett, G. (2000) Evaluating "Payback” on Biomedical Research from Papers Cited in Clinical Guidelines: Applied Bibliometric Study. BMJ, 320, 1107-1111. http://dx.doi.org/10.1136/bmj.320.7242.1107

[21] Van de Wiel, M.W.J., Van den Bossche, P., Janssen, S. and Jossberger, H. (2011) Exploring Deliberate Practice in Medicine: How Do Physicians Learn in the Workplace? Advances in Health Sciences Education, 16, 81-95. http://dx.doi.org/10.1007/s10459-010-9246-3

[22] Fuchs, R. and Milstein, A. (2011) The \$640 Billion Question-Why Does Cost-Effective Care Diffuse So Slowly? The New England Journal of Medicine, 364, 1985-1987. http://dx.doi.org/10.1056/NEJMp1104675

[23] Grimshaw, J.M., Eccles, M.P., Walker, A.E., and Thomas, R.E. (2002) Changing Physicians’ Behavior: What Works and Thoughts on Getting More Things to Work. Journal of Continuing Education in the Health Professions, 22, 237243. http://dx.doi.org/10.1002/chp.1340220408

[24] Keaney Jr., J.F., Curfman, G.D. and Jarcho, J.A. (2014) A Pragmatic View of the New Cholesterol Treatment Guidelines. The New England Journal of Medicine, 370, 275-278. http://dx.doi.org/10.1056/NEJMms1314569

[25] Stone, N.J., Robinson, J.G., Lichtenstein, A.H., Goff Jr., D.C., Lloyd-Jones, D.M., Amith Jr., S.C., et al. (2014) Treatment of Blood Cholesterol to Reduce Atherosclerotic Cardiovascular Disease Risk in Adults: Synopsis of the 2013 ACC/AHA Cholesterol Guidelines. Annals of Internal Medicine, 160, 339-343. http://dx.doi.org/10.7326/M14-0126

[26] Civeira, F., Ascaso, J. and Masana, L. (2014) Should We Forget about Low-Density Lipoprotein Cholesterol? Journal of the American College of Cardiology, 63, 1228-1229. http://dx.doi.org/10.1016/j.jacc.2013.11.054

[27] Sarosi, G.A. (2015) The Tyranny of Guidelines. Annals of Internal Medicine, 163, 562-563. http://dx.doi.org/10.7326/M15-1202

[28] Libby, P. and Theroux, P. (2005) Pathophysiology of Coronary Artery Disease. Circulation, 111, 3481-3488. http://dx.doi.org/10.1161/CIRCULATIONAHA.105.537878

[29] Davies, M.J., Richardson, P.D., Woolf, N., Katz, D.R. and Mann, J. (1993) Risk of Thrombosis in Human Atherosclerotic Plaques: Role of Extracellular Lipid, Macrophage, and Smooth Muscle Cell Content. British Heart Journal, 69, 377-381. http://dx.doi.org/10.1136/hrt.69.5.377

[30] Arbab-Zadeh, A., Nakanano, M., Virmani, R. and Fuster, V. (2012) Acute Coronary Events. Circulation, 125, 11471156. http://dx.doi.org/10.1161/CIRCULATIONAHA.111.047431

[31] Yonetsu, T., Kakuta, T., Lee, T., Takahashi, K., Kawaguchi, N. and Yamamoto, G. (2011) In vivo Critical Fibrous Cap Thickness for Rupture-Prone Coronary Plaques Assessed by Optical Coherence Tomography. European Heart Journal, 32, 1251-1259. http://dx.doi.org/10.1093/eurheartj/ehq518

[32] Motoyama, S., Sarai, M., Harigaya, H., Anno, H., Inoue, K., Hara, T., et al. (2009) Computed Tomographic Angiography Characteristics of Atherosclerotic Plaques Subsequently Resulting in Acute Coronary Syndrome. Journal of the American College of Cardiology, 54, 49-57. http://dx.doi.org/10.1016/j.jacc.2009.02.068

[33] Liu, J., Sempos, C., Donahue, R.P., Dorn, J., Trevisan, M. and Grundy, S.M. (2005) Joint Distribution of Non-HDL and LDL Cholesterol and Coronary Heart Disease Risk Prediction among Individuals with and without Diabetes. Diabetes Care, 28, 1916-1921. http://dx.doi.org/10.2337/diacare.28.8.1916

[34] Karalis, D.G. (2007) The Role of Advanced Lipid Testing in Clinical Practice. Preventive Cardiology, 10, $228-234$. http://dx.doi.org/10.1111/j.1520-037X.2007.07333.x

[35] Dayspring, T., Dall, T. and Abuhajir, M. (2010) Moving beyond LDL-C: Incorporating Lipoprotein Particle Numbers and Geometric Parameters, to Improve Clinical Outcomes. Research Reports in Clinical Cardiology, 2010, 1-10. http://dx.doi.org/10.2147/RRCC.S14825

[36] Kannel, W.B. (1988) Contributions of the Framingham Study to the Conquest of Coronary Artery Disease. The American Journal of Cardiology, 62, 1109-1112. http://dx.doi.org/10.2147/RRCC.S14825

[37] Landmesser, U., Hornig, B. and Drexler, H. (2004) Endothelial Function: A Critical Determinant in Atherosclerosis? 
Circulation, 109, II-27-II-33. http://dx.doi.org/10.1161/01.CIR.0000129501.88485.1f

[38] Berliner, J.A. and Heinecke, J.W. (1996) The Role of Oxidized Lipoproteins in Atherogenesis. Free Radical Biology and Medicine, 20, 707-727. http://dx.doi.org/10.1016/0891-5849(95)02173-6

[39] Palmer, S.C., Craig, J.C., Navaneethan, S.D., Tonelli, M., Pellegrini, F. and Strippoli, G.F.M. (2012) Benefits and Harms of Statin Therapy for Persons with Chronic Kidney Disease: A Systematic Review and Meta-Analysis. Annals of Internal Medicine, 157, 263-275. http://dx.doi.org/10.7326/0003-4819-157-4-201208210-00007

[40] Friedewald, W.T., Levy, R.I. and Fredrickson, D.S. (1972) Estimation of the Concentration of Low Density Lipoprotein Cholesterol in Plasma, without Use of the Preparative Ultracentrafuge. Clinical Chemistry, 18, 499-502.

[41] Martin, S.S., Blaha, M.J., Elshazly, M.B., Toth, P.P., Kwiterovich, P.O., Blumenthal, R.S., et al. (2013) Comparison of a Novel Method vs. the Friedenwald Equation for Estimating Low-Density Lipoprotein Cholesterol Levels from the Standard Lipid Profile. JAMA, 310, 2061-2068. http://dx.doi.org/10.1001/jama.2013.280532

[42] Ridker, P.M., Danielson, E., Fonseca, F.A.H., Genest, J., Gotto, A.M., Kastelein, J.J.P., et al. (2008) Rosuvastatin to Prevent Vascular Events in Men and Women with Elevated C-Reactive Protein. The New England Journal of Medicine, 359, 2195-2207. http://dx.doi.org/10.1056/NEJMoa0807646

[43] Brown, M.S., Anderson, R.G. and Goldstein, J.L. (1983) Recycling Receptors: The Round-Trip Itinerary of Migrant Membrane Proteins. Cell, 32, 663-667. http://dx.doi.org/10.1016/0092-8674(83)90052-1

[44] Cohen, J.C., Boerwinkle, E., Mosley Jr., T.H. and Hobbs, H.H. (2006) Sequence Variations in PCSK9, Low LDL, and Protection against Coronary Heart Disease. The New England Journal of Medicine, 354, 1264-1272. http://dx.doi.org/10.1056/NEJMoa054013

[45] Baigent, C., Blackwell, L., Emberson, J., Holland, L.E., Reith, C. and Cholesterol Treatment Trialists (CTT) Collaboration (2010) Efficacy and Safety of More Intensive Lowering of LDL Cholesterol: A Meta-Analysis of Data from 170,000 Participants in 26 Randomised Trials. The Lancet, 376, 1670-1681. http://dx.doi.org/10.1016/S0140-6736(10)61350-5

[46] Law, M.R., Wald, N.J. and Rudnicka, A.R. (2003) Quantifying Effect of Statins on Low Density Lipoprotein Cholesterol, Ischaemic Heart Disease, and Stroke: Systematic Review and Meta-Analysis. BMJ, 326, 1423-1427. http://dx.doi.org/10.1136/bmj.326.7404.1423

[47] Myers, J., Prakash, M., Froelicher, V., Do, D., Partington, S., and Atwood, J.E. (2002) Exercise Capacity and Mortality among Men Referred for Exercise Testing. The New England Journal of Medicine, 346, 793-801. http://dx.doi.org/10.1056/NEJMoa011858

[48] McMurry, M.P., Connor, W.E. and Cerqueira, M.T. (1982) Dietary Cholesterol and the Plasma Lipids and Lipoproteins in the Tarahumara Indians: A People Habituated to a Low Cholesterol Diet after Weaning. American Journal of Clinical Nutrition, 35, 741-744.

[49] Connor, W.E., Hodges, R.E. and Bleiler, R.E. (1961) The Serum Lipids in Men Receiving High Cholesterol and Cholesterol-Free Diets. Journal of Clinical Investigation, 40, 894-901. http://dx.doi.org/10.1172/JCI104324

[50] Pfeffer, A., Claggett, B., Diaz, R., Dickstein, K., Gerstein, H.C., Kober, L.V., et al. (2015) Lixisenatide in Patients with Type 2 Diabetes and Acute Coronary Syndrome. The New England Journal of Medicine, 373, 2247-2257. http://dx.doi.org/10.1056/NEJMoa1509225

[51] Gordon, D.J., Probstfield, J.L., Garrison, R.J., Neaton, J.D., Castelli, W.P., Knoke J.D., et al. (1989) High-Density Lipoprotein Cholesterol and Cardiovascular Disease. Four Prospective American Studies. Circulation, 79, 8-15. http://dx.doi.org/10.1161/01.CIR.79.1.8

[52] Nicholls, S.J., Tuzcu, M., Sipahi, I., Grasso, A.W., Schoenhagen, P., Hu, T., et al. (2007) Statins, High-Density Lipoprotein Cholesterol, and Regression of Coronary Atherosclerosis. JAMA, 297, 499-508. http://dx.doi.org/10.1001/jama.297.5.499

[53] Boden, W., The AIM-HIGH Investigators (2011) Niacin in Patients with Low HDL Cholesterol Levels Receiving Intensive Statin Therapy. The New England Journal of Medicine, 365, 2255-2267. http://dx.doi.org/10.1056/NEJMoa1107579

[54] Van Lenten, B.J., Hama, S.Y., de Beer, F.C., Stafforini, D.M., McIntyre, T.M. and Prescott, S.M. (1995) Anti-Inflammatory HDL Becomes Pro-Inflammatory during the Acute Phase Response, LOSS of Protective Effect of HDL against LDL Oxidation in Aortic Wall Cell Cocultures. Journal of Clinical Investigation, 96, 2758-2767. http://dx.doi.org/10.1172/JCI118345

[55] Greenland, P., Knoll, M.D., Stamler, J., Neaton, J.D., Dyer, A.R., Garside, D.B., et al. (2003) Major Risk Factors as Antecedents of Fatal and Nonfatal Coronary Heart Disease Events. JAMA, 290, 891-897. http://dx.doi.org/10.1001/jama.290.7.891

[56] Hu, F.B. and Willett, W.C. (2002) Optimal Diets for the Prevention of Heart Disease. JAMA, 288, 2569-2578. http://dx.doi.org/10.1001/jama.288.20.2569 
[57] Mokdad, A.H., Serdula, M.K., Dietz, W.H., Bowman, B.A., Marks, J.S. and Koplan, J.K. (1999) The Spread of the Obesity Epidemic in the United States, 1991-1998. JAMA, 282, 1519-1522.

http://dx.doi.org/10.1001/jama.282.16.1519

[58] Mamudu, H.M., Paul, T.K., Veeranki, S.P. and Budoff, M. (2014) The Effects of Coronary Artery Calcium Screening on Behavioral Modification, Risk Perception, and Medication Adherence among Asymptomatic Adults: A Systematic Review. Atherosclerosis, 236, 338-350. http://dx.doi.org/10.1016/j.atherosclerosis.2014.07.022

[59] Kalia, N.K., Miller, L.G., Nasir, K., Blumenthal, R.S., Agrawal, N. and Budoff, M.J. (2006) Visualizing Coronary Calcium Is Associated with Improvements in Adherence to Statin Therapy. Atherosclerosis, 185, 394-399. http://dx.doi.org/10.1016/j.atherosclerosis.2005.06.018

[60] Naghavi, M., Falk, E., Hecht, H.S., Jamieson, M.J., Kaul, S., Berman, D., et al. (2006) From Vulnerable Plaque to Vulnerable Patient-Part III: Executive Summary of the Screening for Heart Attack Prevention and Education (SHAPE) Task Force Report. American Journal of Cardiology, 98, 2H-15H. http://dx.doi.org/10.1016/j.amjcard.2006.03.002

[61] Davidson, M.H. (2005) Reducing Residual Risk for Patients on Statin Therapy: The Potential Role of Combination Therapy. The American Journal of Cardiology, 96, 3-13. http://dx.doi.org/10.1016/j.amjcard.2005.08.002

[62] Sachdeva, A., Cannon, C.P., Deedwania, P.C., Labaresh, K.A., Smith Jr., S.C., Dai, D., et al. (2009) Lipid Levels in Patients Hospitalized with Coronary Artery Disease: An Analysis of 136,905 Hospitalizations in Get with the Guidelines. American Heart Journal, 157, 111-117.e2. http://dx.doi.org/10.1016/j.ahj.2008.08.010

[63] Nissen, S.E., Nicholls, S.J., Sipahi, I., Libby, P., Raichlen, J.S., Ballantyne, C.M., et al. (2006) Effect of Very HighIntensity Statin Therapy on Regression of Coronary Atherosclerosis. The ASTEROID Trial. JAMA, 295, 1556-1565. http://dx.doi.org/10.1001/jama.295.13.jpc60002

[64] Jarcho, J.A. and Keaney Jr., J.F. (2015) Proof That Lower Is Better-LDL Cholesterol and IMPROVE-IT. The New England Journal of Medicine, 372, 2448-2450. http://dx.doi.org/10.1056/NEJMe1507041

[65] Goldstein, J.L. and Brown, M.S. (2009) History of Discovery: The LDL Receptor. Arteriosclerosis, Thrombosis, and Vascular Biology, 29, 431-438. http://dx.doi.org/10.1161/ATVBAHA.108.179564

[66] Bilheimer, D.W., Goldstein, J.L., Grundy, S.M., Starzi, T.E. and Brown, M.S. (1984) Liver Transplantation to Provide Low-Density-Lipoprotein Receptors and Lower Plasma Cholesterol in a Child with Homozygous Familial Hypercholesterolemia. The New England Journal of Medicine, 311, 1658-1664. http://dx.doi.org/10.1056/NEJM198412273112603

[67] Goldstein, J.L., Anderson, R.G.W. and Brown, M.S. (1979) Coated Pits, Coated Vesicles, and Receptor-Mediated Endocytosis. Nature, 279, 679-685. Http://Dx.Doi.Org/10.1038/279679a0

[68] Hiro, T., Kimura, T., Morimoto, T., Miyauchi, K., Nakagawa, Y., et al. (2009) Effect of Intensive Statin Therapy on Regression of Coronary Atherosclerosis in Patients with Acute Coronary Syndrome. Journal of the American College of Cardiology, 54, 293-302. http://dx.doi.org/10.1016/j.jacc.2009.04.033

[69] Nicholls, S.J., Ballantyne, C.M., Barter, P.J., Chapman, J., Erbel, R.M., Libby, P., et al. (2011) Effect of Two Intensive Statin Regimens on Progression of Coronary Disease. The New England Journal of Medicine, 365, 2078-2087. http://dx.doi.org/10.1056/NEJMoa1110874

[70] Stegman, B., Puri, R., Cho, L., Shao, M., Ballantyne, C.M., Barter, P.J., et al. (2014) High-Intensity Statin Therapy Alters the Natural History of Diabetic Coronary Atherosclerosis: Insights from SATURN. Diabetes Care, 37, 31143120. http://dx.doi.org/10.2337/dc14-1121

[71] Study of the Effectiveness of Additional Reductions in Cholesterol and Homocysteine Collaborative Group (2010) Intensive Lowering of LDL Cholesterol with $80 \mathrm{mg}$ versus $20 \mathrm{mg}$ Simvastatin Daily in 12,064 Survivors of Myocardial Infarction: A Double-Blind Randomized Trial. The Lancet, 376, 1658-1669. http://dx.doi.org/10.1016/S0140-6736(10)60310-8

[72] Wiviott, S.D., Cannon, C.P., Morrow, D.A., Ray, K.K., Pfeffer, M.A., Braunwald, E. and the PROVE IT-TIMI 22 Investigators. (2005) Can Low-Density lipoprotein Be Too Low? The Safety and Efficacy of Achieving Very Low Low-Density Lipoprotein with Intensive Statin Therapy-A Prove IT-TIMI 22 Substudy. Journal of the American College of Cardiology, 46, 1411-1416. http://dx.doi.org/10.1016/j.jacc.2005.04.064

[73] Santini, S.A., Carrozza, C., Lulli, P., Zuppi, C., CarloTonolo, G. and Musumeci, S. (2003) Atorvastatin Does Not Affect Gonadal or Adrenal Hormones in Type 2 Diabetes with Mild to Moderate Hypercholesterolemia. Journal of Atherosclerosis and Thrombosis, 10, 160-164. http://dx.doi.org/10.5551/jat.10.160

[74] O’Keefe, J.H., Cordain, L., Harris, W.H., Moe, R.M. and Vogel, R. (2004) Optimal Low-Density Lipoprotein Is 50 to 70 mg/dl: Lower Is Better and Physiologically Normal. Journal of the American College of Cardiology, 43, 2142-2146. http://dx.doi.org/10.1016/j.jacc.2004.03.046

[75] Van Biervliet, J.P., Rosseneu, M., Bury, J., Caster, H., Stul, M.S. and Lamote, R. (1986) Apolipoprotein and Lipid 
Composition of Plasma Lipoproteins in Neonates during the First Month of Life. Pediatric Research, 20, 324-328. http://dx.doi.org/10.1203/00006450-198604000-00009

[76] Parker Jr., C.R., Carr, B.R., Simpson, E.R. and MacDonald, P.C. (1983) Decline in the Concentration of Low-Density Lipoprotein-Cholesterol in Human Fetal Plasma near Term. Metabolism-Clinical and Experimental, 32, 919-923. http://dx.doi.org/10.1016/0026-0495(83)90207-X

[77] Robinson, J.G., Nedergaaard, B.S., Rogers, W.J., Fialkow, J., Neutel, J.M., Ramstad, D., et al. (2014) Effect of Evolocumab or Ezetimibe Added to Moderate- or High-Intensity Statin Therapy on LDL-C Lowering in Patients with Hypercholesterolemia: The LAPLACE-2 Randomized Clinical Trial. JAMA, 311, 1870-1882. http://dx.doi.org/10.1001/jama.2014.4030

[78] Sabatine, M.S., Giugliano, R.P., Wiviott, S.D., Raal, F.J., Blom, D.J., Robinson, J., et al., Open-Label Study of Long-Term Evaluation against LDL Cholesterol (OSLER) Investigators (2015) Efficacy and Safety of Evolocumab in Reducing Lipids and Cardiovascular Events. The New England Journal of Medicine, 372, 1500-1509. http://dx.doi.org/10.1056/NEJMoa1500858

[79] Zhao, Z., Tuakli-Wosornu, Y., Lagace, T.A., Kinch, L., Grishin, N.V., Horton, J.D., et al. (2006) Molecular Characterization of Loss-of-Function Mutations in PCSK9 and Identification of a Compound Heterozygote. American Journal of Human Genetics, 79, 514-523. http://dx.doi.org/10.1086/507488

[80] Ridker, P.M. and Wilson, P.W.F. (2013) A Trial-Based Approach to Statin Guidelines. JAMA, 310, 1123-1124. http://dx.doi.org/10.1001/jama.2013.276529

[81] LaRosa, J.C., Grundy, S.M., Waters, D.D., Shear, C., Barter, P., Fruchart, J.C., et al. (2005) Intensive Lipid Lowering with Atorvastatin in Patients with Stable Coronary Disease. The New England Journal of Medicine, 352, 1425-1435. http://dx.doi.org/10.1056/NEJMoa050461

[82] Olsson, A.G., Pears, J., McKellar, J., Mizan, J. and Raza, A. (2001) Effect of Rosuvastatin on Low-Density Lipoprotein Cholesterol in Patients with Hypercholesterolemia. American Journal of Cardiology, 88, 504-508. http://dx.doi.org/10.1016/S0002-9149(01)01727-1

[83] Colhoun, H.M., Betteridge, D.J., Durrington, P.N., Hitman, G.A., Neil, H.A., Livingstone, S.J., et al. (2004) Primary Prevention of Cardiovascular Disease with Atorvastatin in Type 2 Diabetes in the Collaborative Atorvastatin Diabetes Study (CARDS): Multicenter Randomized Placebo-Controlled Trial. The Lancet, 364, 685-696. http://dx.doi.org/10.1016/S0140-6736(04)16895-5

[84] Knopp, R.H., D’Emden, M., Smilde, J.G., Pocock, S.J. and on behalf of the ASPEN Study Group (2006) Efficacy and Safety of Atorvastatin in the Prevention of Cardiovascular End Points in Subjects with Type 2 Diabetes: The Atorvastatin Study for Prevention of Coronary Heart Disease Endpoints in Non-Insulin Dependent Diabetes Mellitus (ASPEN). Diabetes Care, 29, 1478-1485. http://dx.doi.org/10.2337/dc05-2415

[85] Reid, F.D.A., Cook, D.G. and Whincup, P.H. (2002) Use of Statins in the Secondary Prevention of Coronary Heart Disease: Is Treatment Equitable? Heart, 88, 15-19. http://dx.doi.org/10.1136/heart.88.1.15

[86] Zeb, I., Li, D., Nasir, K., Malpeso, J., Batool, A., Flores, F., et al. (2013) Effect of Statin Treatment on Coronary Plaque Progression-A Serial Coronary CT Angiography Study. Atherosclerosis, 231, 198-204. http://dx.doi.org/10.1016/j.atherosclerosis.2013.08.019

[87] Burgstahler, C., Reimann, A., Beck, T., Kuettner, A., Baumann, D., Heuschmid, M., et al. (2007) Influence of Lipid Lowering Therapy on Calcified and Noncalcified Plaques Monitored by Multislice Detector Computed Tomography: Results of the New Age II Pilot Study. Investigative Radiology, 42, 189-195. http://dx.doi.org/10.1097/01.rli.0000254408.96355.85

[88] Nakamura, T., Obata, J.E., Kitta, Y., Takano, H., Kobayashi, T., Fujioka, D., et al. (2008) Rapid Stabilization of Vulnerable Carotid Plaque within 1 Month of Pitavastatin Treatment in Patients with Acute Coronary Syndrome. Journal of Cardiovascular Pharmacology, 51, 365-371. http://dx.doi.org/10.1097/FJC.0b013e318165dcad

[89] Takarada, S., Imanishi, T., Kubo, T., Tanimoto, T., Kitabata, H., Nakamura, N., et al. (2009) Effect of Statin Therapy on Coronary Fibrous-Cap Thickness in Patients with Acute Coronary Syndrome: Assessment by Optical Coherence Tomography Study. Atherosclerosis, 202, 491-497. http://dx.doi.org/10.1016/j.atherosclerosis.2008.05.014

[90] Newman, C.B. and Tobert, J.A. (2015) Statin Intolerance. Reconciling Clinical Trials and Clinical Experience. JAMA, 313, 1011-1012. http://dx.doi.org/10.1001/jama.2015.1335

[91] Aubert, R.E., Yao, J., Xia, F. and Garavaglia, S.B. (2010) Is There a Relationship between Early Statin Compliance and a Reduction in Healthcare Utilization? American Journal of Managed Care, 16, 459-466.

[92] Taylor, A.J., Bindeman, J., Feuerstein, I., Cao, F., Brazaitis, M. and O’Malley, P.G. (2005) Coronary Calcium Independently Predicts Incident Premature Coronary Heart Disease over Measured Cardiovascular Risk Factors: Mean Three-Year Outcomes in the Prospective Army Coronary Calcium (PACC) Project. Journal of the American College of Cardiology, 46, 807-814. http://dx.doi.org/10.1016/j.jacc.2005.05.049 
[93] Brugts, J.J., Yetgin, T., Hoeks, S.E., Gotto, A.M., Shepherd, J., Westendorp, R.G.J., de Craen, A.J.M., et al. (2009) The Benefits of Statins in People without Established Cardiovascular Disease but with Cardiovascular Risk Factors: Meta-Analysis of Randomized Controlled Trials. BMJ, 338, b2376. http://dx.doi.org/10.1136/bmj.b2376

[94] FDA Contributors (2012) FDA Drug Safety Communication: Important Safety Label Changes to Cholesterol-Lowering Statin Drugs. http://www.fda.gov/Drugs/DrugSafety/ucm293101.htm

[95] Pedersen, T.R., Olsson, A.G., Faergeman, O., Kjekshus, J., Wedel, H., Berg, K., et al. (1998) Lipoprotein Changes and Reduction in the Incidence of Major Coronary Heart Disease Events in the Scandinavian Simvastatin Survival Study (4S). Circulation, 97, 1453-1460. http://dx.doi.org/10.1161/01.CIR.97.15.1453

[96] Joy, T.R., Monjed, A., Zou, G.Y., Hegele, R.A., McDonald, C.G. and Mahon, J.L. (2014) N-of-1 (Single-Patient) Trials for Statin-Related Myalgia. Annals of Internal Medicine, 160, 301-310. http://dx.doi.org/10.7326/M13-1921

[97] Meek, C., Wierzbicki, A.S., Jewkes, C., Twomey, P.J., Crook, M.A., Jones, A., et al. (2012) Daily and Intermittent Rosuvastatin 5 mg Therapy in Statin Intolerant Patients: An Observational Study. Current Medical Research and Opinion, 28, 371-378. http://dx.doi.org/10.1185/03007995.2012.657302

[98] Thompson, P.D., Clarkson, P. and Karas, R.H. (2003) Statin-Associated Myopathy. JAMA, 289, 1681-1690. http://dx.doi.org/10.1001/jama.289.13.1681

[99] Harper, C.R. and Jacobson, T.A. (2007) The Broad Spectrum of Statin Myopathy: From Myalgia to Rhabdomyolysis. Current Opinion in Lipidology, 18, 401-408. http://dx.doi.org/10.1097/MOL.0b013e32825a6773

[100] DuBroff, R.J. (2015) The Statin Diabetes Conundrum: Short-Term Gain, Long-Term Risk or Inconvenient Truth? Evidence-Based Medicine, 20, 121-123. http://dx.doi.org/10.1136/ebmed-2015-110236

[101] Sukhija, R., Prayaga, S., Marashdeh, M., Bursac, Z., Kakar, P., Bansal, D., et al. (2009) Effect of Statins on Fasting Plasma Glucose in Diabetic and Nondiabetic Patients. Journal of Investigative Medicine, 57, 495-499.

[102] Nawrocki, J.W., Weiss, S.R., Davidson, M.H., Sprecher, D.L., Schwartz, S.L., Lupien, P.-J., et al. (1995) Reduction of LDL Cholesterol by 25\% to 60\% in Patients with Primary Hypercholesterolemia by Atorvastatin, a New HMG-CoA Reductase Inhibitor. Arteriosclerosis, Thrombosis, and Vascular Biology, 15, 678-682. http://dx.doi.org/10.1161/01.ATV.15.5.678

[103] Cannon, C.P., Blazing, M.A., Giugliano, R.P., McCagg, A., White, J.A., Theroux, P., et al. (2015) Ezetimibe Added to Statin Therapy after Acute Coronary Syndromes. The New England Journal of Medicine, 372, 2387-2397. http://dx.doi.org/10.1056/NEJMoa1410489

[104] DeGoma, E.M. (2014) Review: Statins Are Not Associated with Cognitive Impairment, Alzheimer Disease, or Dementia. American College of Physicians Journal Club, 160, JC10.

[105] Richardson, K., Schoen, M., French, B., Umscheid, C.A., et al. (2013) Statins and Cognitive Function: A Systematic Review. Annals of Internal Medicine, 159, 688-697. http://dx.doi.org/10.7326/0003-4819-159-10-201311190-00007

[106] Swiger, K.J., Manalac, R.J., Blumenthal, R.S., Blaha, M.J. and Martin, S.S. (2013) Statins and Cognition: A Systematic Review and Meta-Analysis of Short- and Long-Term Cognitive Effects. Mayo Clinic Proceedings, 88, 1213-1221. http://dx.doi.org/10.1016/j.mayocp.2013.07.013

[107] Dikkers, A. and Tietge, U.J. (2010) Biliary Cholesterol Secretion: More Than a Simple ABC. World Journal of Gastroenterology, 16, 5936-5945.

[108] Sudhop, T., Lutjohann, D., Kodal, A., Igel, M., Tribble, D.L., Shah, S., et al. (2002) Inhibition of Intestinal Cholesterol Absorption by Ezetimibe in Humans. Circulation, 106, 1943-1948. http://dx.doi.org/10.1161/01.CIR.0000034044.95911.DC

[109] Silbernagel, G., Chapman, M.J., Genser, B., Kleber, M.E., Fauler, G., Scharnagl, H., et al. (2013) High Intestinal Cholesterol Absorption Is Associated with Cardiovascular Disease and Risk Alleles in ABCG8 and ABO: Evidence from the LURIC and YFS Cohorts and from a Meta-Analysis. Journal of the American College of Cardiology, 62, 291-299. http://dx.doi.org/10.1016/j.jacc.2013.01.100

[110] Altmann, S.W., Davis Jr., H.R., Zhu, L.J., Yao, X., Hoos, L.M., Tetzloff, G., Iyet, S.P., Maguire, M., Golovko, A., Zeng, M., Wang, L., Murgolo, N. and Graziano, M.P. (2004) Niemann-Pick C1 Like 1 Protein Is Critical for Intestinal Cholesterol Absorption. Science, 303, 1201-1204. http://dx.doi.org/10.1126/science.1093131

[111] Lauridsen, B.K., Sstender, S., Frikke-Schmidt, R., Nordestgaard, B.G. and Tybjaerg-Hansen, A. (2015) Genetic Variation in the Cholesterol Transporter NPC1L1, Ischaemic Vascular Disease, and Gallstone Disease. European Heart Journal, 36, 1601-1608. http://dx.doi.org/10.1093/eurheartj/ehv108

[112] Ference, B.A., Majeed, F., Penumetcha, R., Flack, J.M. and Brook, R.D. (2015) Effect of Naturally Random Allocation to Lower Low-Density Lipoprotein Cholesterol on the Risk of Coronary Heart Disease Mediated by Polymorphisms in NPC1L1, HMGCR, or Both: A $2 \times 2$ Factorial Mendelian Randomization Study. Journal of the American College of Cardiology, 65, 1552-1561. http://dx.doi.org/10.1016/j.jacc.2015.02.020 
[113] Stitziel, N.O., The Myocardial Infarction Genetics Consortium Investigators (2014) Inactivating Mutations in NPC1L1 and Protection from Coronary Heart Disease. The New England Journal of Medicine, 371, 2072-2082. http://dx.doi.org/10.1056/NEJMoa1405386

[114] Gagné, C., Bays, H.E., Weiss, S.R., Mata, P., Quinto, K., Melino, M., et al. (2002) Efficacy and Safety of Ezetimibe Added to Ongoing Statin Therapy for Treatment of Patients with Primary Hypercholesterolemia. American Journal of Cardiology, 90, 1084-1091. http://dx.doi.org/10.1016/S0002-9149(02)02774-1

[115] Maron, D.J., Hartigan, P.M., Neff, D.R., Weintraub, W.S. and Boden, W.E., COURAGE Trial Investigators (2013) Impact of Adding Ezetimibe to Statin to Achieve Low-Density Lipoprotein Cholesterol Goal (from the Clinical Outcomes Utilizing Revascularization and Aggressive Drug Evaluation [COURAGE] Trial). American Journal of Cardiology, 111, 1557-1562. http://dx.doi.org/10.1016/j.amjcard.2013.02.005

[116] Blom, D.J, Hala, T., Bolognese, M., Lillestol, M.J., Toth, P.D., Burgess, L., et al. (2014) A 52-Week Placebo-Controll ed Trial of Evolocumab in Hyperlipidemia. The New England Journal of Medicine, 370, 1809-1819. http://dx.doi.org/10.1056/NEJMoa1316222

[117] Lipinski, M.J., Benedetto, U., Escarcega, R.O., Blondi-Zoccai, G., Lhermusier, T., Baker, N.C., et al. (2015) The Impact of Proprotein Convertase Subtilisin-Kexin Type 9 Serine Proteast Inhibitors on Lipid Levels and Outcomes in Patients with Primary Hypercholesterolaemia: A Network Meta-Analysis. European Heart Journal, 37, 536-545. http://dx.doi.org/10.1093/eurheartj/ehv563.

[118] Lambert, G., Sjouke, B., Choque, B., Kastelein, J.J. and Hovingh, G.K. (2012) The PCSK9 Decade. Thematic Review Series: New Lipid and Lipoprotein Targets for the Treatment of Cardiometabolic Diseases. Journal of Lipid Research, 53, 2515-2524. http://dx.doi.org/10.1194/jlr.R026658

[119] Welder, G., Zineh, I., Pacanowski, M.A., Troutt, J.S., Cao, G. and Konrad, R.J. (2010) High-Dose Atorvastatin Causes a Rapid Sustained Increase in Human Serum PCSK9 and Disrupts Its Correlation with LDL Cholesterol. Journal of Lipid Research, 51, 2714-2721. http://dx.doi.org/10.1194/jlr.M008144

[120] Navarese, E.P., Kolodziejczak, M., Schulze, V., Gurbel, P.A., Tantry, U., Lin Y., et al. (2015) Effects of Proprotein Convertase Subtilisin/Kexin Type 9 Antibodies in Adults with Hypercholesterolemia: A Systematic Review and Meta-Analysis. Annals of Internal Medicine, 163, 40-51. http://dx.doi.org/10.7326/M14-2957

[121] Huijgen, R., Boekholdt, S.M., Arsenault, B.J., Bao, W., Davaine, J.-M., Tabet, F., et al. (2012) Plasma PCSK9 Levels and Clinical Outcomes in the TNT (Treating to New Targets) Trial: A Nested Case-Control Study. Journal of the American College of Cardiology, 59, 1778-1784. http://dx.doi.org/10.1016/j.jacc.2011.12.043

[122] Barter, P., Gotto, A.M., LaRosa, J.C., Maroni, J., Szarek M., Grundy, S.M., et al. (2007) HDL Cholesterol, Very Low Levels of LDL Cholesterol, and Cardiovascular Events. The New England Journal of Medicine, 357, 1301-1310. http://dx.doi.org/10.1056/NEJMoa064278

[123] Ray, K.K., Cannon, C.P., McCabe, C.H., Cairns, R., Tonkin, A.M., Sacks, F.M., et al. (2005) Early and Late Benefits of High-Dose Atorvastatin in Patients with Acute Coronary Syndromes: Results From the PROVE IT-TIMI 22 Trial. Journal of the American College of Cardiology, 46, 1405-1410. http://dx.doi.org/10.1016/j.jacc.2005.03.077

[124] Akram, O.N., Bernier, A., Petrides, F., Wong, G. and Lambert, G. (2010) Beyond LDL Cholesterol, a New Role for PCSK9. Arteriosclerosis, Thrombosis, and Vascular Biology, 30, 1279-1281. http://dx.doi.org/10.1161/ATVBAHA.110.209007

[125] Detrano, R., Guerci, A.D., Carr, J., Bild, D.E., Burke, G., Folsom, A.R., et al. (2008) Coronary Calcium as a Predictor of Coronary Events in Four Racial or Ethnic Groups. The New England Journal of Medicine, 358, 1336-1345. http://dx.doi.org/10.1056/NEJMoa072100

[126] Silverman, M.G., Blaha, M.J., Krumholz, H.M., Budoff, M.J., Blankstein, R., Sibley, C.T., et al. (2014) Impact of Coronary Artery Calcium on Coronary Heart Disease Events in Individuals at the Extremes of Traditional Risk Factor Burden: The MULTI-Ethnic Study of Atherosclerosis. European Heart Journal, 35, 2232-2241. http://dx.doi.org/10.1093/eurheartj/eht508

[127] Hecht, H.S. (2015) Coronary Artery Calcium Scanning: Past, Present and Future. JACC: Cardiovascular Imaging, 8, 579-596. http://dx.doi.org/10.1016/j.jcmg.2015.02.006

[128] Keelan, P.C., Bielak, L.F., Ashai, K., Jamjoum, L.S., Denktas, A.E., Rumberger, J.A., et al. (2001) Long-Term Prognostic Value of Coronary Calcification Detected by Electron-Beam Computed Tomography in Patients Undergoing Coronary Angiography. Circulation, 104, 412-417. http://dx.doi.org/10.1161/hc2901.093112

[129] McClelland, R.L., Jorgensen, N.W., Budoff, M., Blaha, M.J., Post, W.S., Kronmal, R.A., et al. (2015) 10-Year Coronary Heart Disease Risk Prediction Using Coronary Artery Calcium and Traditional Risk Factors. Derivation in the MESA (Multi-Ethnic Study of Atherosclerosis) with Validation in the HNR (Heinz Nixdorf Recall) Study and the DHS (Dallas Heart Study). Journal of the American College of Cardiology, 66, 1643-1653. http://dx.doi.org/10.1016/j.jacc.2015.08.035 
[130] Shaw, L.J., Giambrone, A.E., Blaha, M.J., Knapper, J.T., Berman, D.S., Bellam, N., et al. (2015) Long-Term Prognosis after Coronary Artery Calcification Testing in Asymptomatic Patients: A Cohort Study. Annals of Internal Medicine, 163, 14-21. http://dx.doi.org/10.7326/M14-0612

[131] Sangiorgi, G., Rumberger, J.A., Severson, A., Edwards, W.D., Gregoire, J., Fitzpatrick, L.A. and Schwartz, R.S. (1998) Arterial Calcification and Not Lumen Stenosis Is Highly Correlated with Atherosclerotic Plaque Burden in Humans: A Histologic Study of 723 Coronary Artery Segments Using Nondecalcifying Methodology. Journal of the American College of Cardiology, 31, 126-133. http://dx.doi.org/10.1016/S0735-1097(97)00443-9

[132] Baumbart, D., Schermund, A., Goerge, G., Haude, M., Ge, J., Adamzik, M., et al. (1997) Comparison of Electron Beam Computed Tomography with Intracoronary Ultrasound and Coronary Angiography for Detection of Coronary Atherosclerosis. Journal of the American College of Cardiology, 30, 57-64. http://dx.doi.org/10.1016/S0735-1097(97)00147-2

[133] Yeh, V., Nakanishi, R. and Budoff, M.J. (2015) Coronary Artery Disease Progression, Insights from CT. Current Cardiovascular Imaging Reports, 8, 24. http://dx.doi.org/10.1007/s12410-015-9341-1

[134] Douglas, P.S., Hoffmann, U., Patel, M.R., Mark, D.B., Al-Khalidi, H.R., Cavanaugh, B., et al. (2015) Outcomes of Anatomical versus Functional Testing for Coronary Artery Disease. The New England Journal of Medicine, 372, 1291-1300. http://dx.doi.org/10.1056/NEJMoa1415516

[135] Orchard, T.J., Costacou, T., Kretowski, A. and Nesto, R.W. (2006) Type 1 Diabetes and Coronary Artery Disease. Diabetes Care, 29, 2528-2538. http://dx.doi.org/10.2337/dc06-1161

[136] Cleary, P.A., Orchard, T.J., Genuth, S., Wong, N.D., Detrano, R., Backlund, J.-Y., et al. (2006) The Effect of Intensive Glycemic Treatment on Coronary Artery Calcification in Type 1 Diabetic Participants of the Diabetes Control and Complications Trial/Epidemiology of Diabetes Intervention and Complications (DCCT/EDIC) Study. Diabetes, 55, 3556-3565. http://dx.doi.org/10.2337/db06-0653

[137] Goff Jr., D.C., Lloyd-Jones, D.M., Bennett, G., Coady, S., D’Agostino, R.B., Gibbons, R., et al., American College of Cardiology/American Heart Association Task Force on Practice Guidelines (2014) 2013 ACC/ AHA Guideline on the Assessment of Cardiovascular Risk: A Report of the American College of Cardiology/American Heart Association Task Force on Practice Guidelines. Journal of the American College of Cardiology, 63, 2935-2959. http://dx.doi.org/10.1016/j.jacc.2013.11.005

[138] Nasir, K., Bittencourt, M.S., Blaha, M.J., Blankstein R., Agatson, A.S., Rivera, J.J., et al. (2015) Implications of Coronary Artery Calcium Testing among Statin Candidates According to American College of Cardiology/American Heart Association Cholesterol Management Guidelines. Journal of the American College of Cardiology, 66, 1657-1668. http://dx.doi.org/10.1016/j.jacc.2015.07.066

[139] Budoff, M.J., McClelland, R.L., Nasir, K., Greenland, P., Kronmal, R.A., Kondos, G.T., et al. (2009) Cardiovascular Events with Absent or Minimal Coronary Calcification: The Multi-Ethnic Study of Atherosclerosis (MESA). American Heart Journal, 158, 554-561. http://dx.doi.org/10.1016/j.ahj.2009.08.007

[140] Tota-Maharaj, R., Blaha, M.J., McEvoy, J.W., Blumenthal, R.S., Muse, E.D., Budoff, M.J., et al. (2012) Coronary Artery Calcium for the Prediction of Mortality in Young Adults $<45$ Years Old and Elderly Adults $>75$ Years Old. European Heart Journal, 33, 2955-2962. http://dx.doi.org/10.1093/eurheartj/ehs230

[141] Budoff, M.J., Young, R., Lopez, V.A., Kronmal, R.A., Nasir, K., et al. (2013) Progression of Coronary Calcium and Incident Coronary Heart Disease Events: MESA (Multi-Ethnic Study of Atherosclerosis). Journal of the American College of Cardiology, 61, 1231-1239. http://dx.doi.org/10.1016/j.jacc.2012.12.035

[142] Puri, R., Nicholls, S.J., Shao, M., Kataoka, K.Y., Uno, K., Kapadia, S.R., Tuzcu, E.M. and Nissen, S.E. (2015) Impact of Statins on Serial Coronary Calcification during Atheroma Progression and Regression. Journal of the American College of Cardiology, 65, 1273-1282. http://dx.doi.org/10.1016/j.jacc.2015.01.036

[143] Budoff, M.J., Yu, D., Nasir, K., Mehrotra, R., Chen, L., Takasu, J., Agrawal, N., Liu, S.T. and Blumenthal, R.S. (2005) Diabetes and Progression of Coronary Calcium under the Influence of Statin Therapy. American Heart Journal, 149, 695-700. http://dx.doi.org/10.1016/j.ahj.2004.07.034

[144] Lazar, L.D., Pletcher, M.J., Coxson, P.G., Bibbins-Domingo, K. and Goldman, L. (2011) Cost-Effectiveness of Statin Therapy for Primary Prevention in a Low-Cost Statin Era. Circulation, 124, 146-153. http://dx.doi.org/10.1161/CIRCULATIONAHA.110.986349

[145] Asch, D.A., Troxel, A.B., Stewart, W.F., Sequist, T.D., Jones, J.B., Hirsch, A.G., et al. (2015) Effect of Financial Incentives to Physicians, Patients, or Both on Lipids Levels: A Randomized Clinical Trial. JAMA, 314, 1926-1935. http://dx.doi.org/10.1001/jama.2015.14850

[146] Perk, J., De Backer, G., Gohlke, H., Graham, I., Reiner, Z., Verschuren, W.M.M., et al. (2012) European Guidelines on Cardiovascular Disease Prevention in Clinical Practice (Version 2012). European Heart Journal, 33, 1635-1701. http://dx.doi.org/10.1093/eurheartj/ehs092 